\title{
IMPLEMENTASI PEMBELAJARAN TEMATIK INTEGRATIF BERBASIS KARAKTER DI SDIT KOTA JAMBI
}

\author{
${ }^{1}$ Umil Muhsinin, ${ }^{2}$ Kholid Musyaddad, ${ }^{3}$ Fauzan Azim \\ ningsihsyukrya@gmail.com \\ ${ }^{1,2,3}$ Universitas Islam Negeri Sultan Thaha Saifudin Jambi
}

\begin{abstract}
.
The 2013 curriculum aims to improve the balance between spiritual competencies, attitudes, knowledge, and skills. One way is to implement integrative thematic learning in elementary schools. The purpose of this study was to describe how the implementation of integrative thematic learning in SDIT Jambi City. This research method uses a descriptive qualitative approach. The sampling technique used was purposive sampling. Data were analyzed by data analysis model of Hiles and Huberman. Test the validity of data with perseverance of observation and triangulation of sources and techniques. The results of the study describe the implementation of integrative thematic learning at the stage of preparation, learning process, and assessment. The conclusions of this paper: (a) Character-based thematic learning planning in SDIT Kota Jambi has shown the integration of character values in thematic learning, which is supported by the integration of integrated curriculum in SDIT Jambi City; (b) The implementation of thematic learning does not work in accordance with the planning, but does not eliminate the purpose of learning and the integration of character values, because the active days in the SDIT of Jambi City are only five days; and (c) Thematic learning assessment in Jambi City SDIT was conducted using authentic assessment.
\end{abstract}

\section{Keywords: Integrative thematic, character}

\begin{abstract}
Abstrak.
Tujuan dari penulisan ini Implementasi Pembelajaran Tematik Integratif Berbasis Karakter Di Sdit Kota Jambi untuk meningkatkan keseimbangan antara kompetensi spiritual, sikap, pengetahuan, dan keterampilan. Salah satu caranya dengan menerapkan pembelajaran tematik integratif di sekolah dasar. Tujuan penelitian ini adalah untuk mendeskripsikan bagaimana implementasi pembelajaran tematik integratif di SDIT Kota Jambi. Metode penelitian ini menggunakan pendekatan kualitatif deskriptif. Teknik sampling yang digunakan adalah purposive sampling. Data dianalisis dengan analisis data model Hiles dan Huberman. Uji keabsahan data dengan ketekunan pengamatan dan triangulasi sumber dan teknik. Hasil penelitian mendeskripsikan tentang implementasi pembelajaran tematik integratif pada tahap persiapan, proses pembelajaran, dan penilaian. Kesimpulan penulisan ini : (a) Perencanaan pembelajaran tematik berbasis karakter di SDIT Kota Jambi sudah menunjukkan adanya pengintegrasian nilai-nilai karakter dalam pembelajaran tematik, yang didukung dengan adanya pengintegrasian kurikulum keterpaduan di SDIT Kota Jambi; (b) Pelaksanaan pembelajaran tematik tidak berjalan sesuai dengan perencanaan, namun tidak menghilangkan tujuan pembelajaran dan pengintegrasian nilai karakter, dikarenakan hari aktif yang berlaku di SDIT Kota Jambi hanya lima hari; dan (c) Penilaian pembelajaran tematik di SDIT Kota Jambi dilakukan dengan menggunakan penilaian autentik.
\end{abstract}

\section{Kata Kunci: Tematik integratif, karakter}




\section{PENDAHULUAN}

Pembelajaran merupakan sebuah kegiatan yang memiliki nilai edukatif (Bahri, 2010). Pembelajaran bukan lagi usaha untuk menyampaikan pengetahuan tetapi juga merubah perilaku peserta didik kearah yang lebih baik, yang dapat menyeimbangkan antara kecerdasan akademik, emosional dan spritual. Hal ini sebagaimana orientasi kurikulum 2013 yang menyatakan bahwa tujuan kurikulum 2013 yaitu terjadinya peningkatan keseimbangan antara kompetensi spiritual, sikap (attitude), keterampilan (skill), dan pengetahuan (knowledge) yang bertujuan untuk membentuk karakter peserta didik.

Upaya pemerintah dalam mengembangkan karakter siswa yaitu dengan memberlakukan kurikulum K-13 yang menekankan pada pengembangan karakter peserta didik dengan cara menerapkan pembelajaran tematik integratif. Pembelajaran tematik integratif adalah pembelajaran terpadu yang menggunakan tema untuk mengaitkan beberapa mata pelajaran sehingga dapat memberikan pengalaman bermakna pada siswa (Trianto, 2011). Pembelajaran tematik juga dikatakan sebagai pembelajaran yang berusaha untuk mengintegrasikan pengetahuan, keterampilan, nilai, atau sikap pembelajaran, serta pemikiran yang kreatif dengan menggunakan sebuah tema (Suryosubroto, 2009). Proses pembelajaran mengacu pada pendekatan saintifik yaitu menggali informasi, melalui pengamatan, bertanya, mengolah informasi dan menyimpulkanya. Kemendikbud menjelaskan bahwa dalam pembelajaran tematik integratif mata pelajaran IPA dan IPS itu tidak dihilangkan, tetapi menjadi objek pembelajaran dalam tematik integratif, artinya kedua bidang itu tidak menjadi mata pelajaran tersendiri, tetapi bergabung ke dalam mata pelajaran yang lain (Kompas, 20015).

Usia sekolah dasar (sekitar 6-12 tahun) merupakan tahap penting bagi pelaksanaan pendidikan karakter. Anak sekolah dasar mengalami perkembangan fisik dan motorik tak terkecuali perkembangan kepribadian, watak emosional, intelektual, bahasa, budi pekerti, dan moralnya yang bertumbuh pesat (Dwi, 2007). Oleh karena itu jika menghendaki pendidikan karakter dapat berhasil maka pelaksanaannya harus dimulai sejak masa kanakkanak dan usia SD/MI. Hasil observasi menemukan, bahwa siswa SIT memiliki karakter yang baik. Hal ini dikarenakan pendidikan karakter merupakan pilar utama dalam proses penyelenggaraannya. SIT menerapkan nilai islam sebagai inspirasi sekaligus pemandu utama dalam proses penyelenggaraan pendidikannya. 
Berdasarkan penelitian yang telah dilakukan oleh Khoiria Hikmawati dengan judul penelitian “Implementasi Pembelajaran Tematik Berbasis Karakter Religius Dan Sosial Di Kelas IV SD Pusmalang” dengan focus penelitian ini ada pada karakter religious dan social dengan hasil penelitian menunjukan bahwa implementasi pembelajaran tematik berbasis karakter religious dan peduali social terdiri dari perencanaan, pelaksanaan, dan evaluai/penilaian. Perencanaan pembelajaran yang digunakan guru sudah menunjukan pengintegrasi karakter religius dan peduli social (Hikmawati, 2018). Penelitian lain yang dilakukan oleh Lilis Tri Karyani dengan judul penelitian “ Implementasi Pemebelajaran Tematik Integratif Dengan Pendekatan Scientific Pada Kelas 5 SD N unggukan Di Kabupaten Purworejo" dengan focus penelitian ada pada pembelajaran menggunakan pendekatan scientific maka hasil penelitian ini menunjukan bahwa 1) Kegiatan awal yaitu dengan berdoa, presensi kehadiran siswa, apersepsi, menyampaikan tujuan pembelajaran, memotivasi, menjelaskan materi yang telah dipelajari pada pembelajaran sebelumnya. 2) Kegiatan Inti sudah menngunakan pendekatan saintifik yaitu, mengamati, menanya, menggunakan infrmasi, menalar, dan mengkomunikasikan sudah diterapkan. 3) kegiatan akhir yaitu berdoa, guru memberi tugas rumah, menyampaikan pembelajaran dipertemuan berikutnya dan memberi evaluasi sikap, pengetahuan dan keterampilan (Tri Karyani, 2017). Berdasarkan paparan di atas, artikel ini bertujuan untuk mendeskripsikan bagaimana "Implementasi Pembelajaran Tematik Integratif Berbasis Karakter pada Siswa di SDIT Kota Jambi"

\section{METODE PENELITIAN}

Penelitian ini bertujuan untuk mendeskripsikan implementasi pembelajaran tematik integratif berbasis karakter di SDIT Kota Jambi, sehingga pendekatan penelitian yang digunakan adalah pendekatan penelitian kualitatif deskriptif. Penelitian ini dilakukan di SDIT Kota Jambi, yaitu SDIT An-Nahl, SDIT Ash-shiddiqi. Waktu penelitian pada bulan April - Mei 2018. Subjek penelitian atau informan dalam penelitian ini adalah kepala sekolah, guru kelas dan siswa SDIT An-Nahl dan SDIT Ash-shiddiqi. Subjek penelitian dipilih dengan cara purposive sampling dan snowball sampling. Data dalam penelitian ini adalah data tentang implementasi pembelajaran tematik integratif berbasis karakter di SDIT Kota Jambi, sehingga data yang dikumpulkan berupa kata-kata, tulisan/catatan, rekaman, dokumen, gambar, dan lain sebagainya. Data dikumpulkan melalui proses 
wawancara mendalam (depth interview) untuk mengumpulkan informasi berupa perkataan lisan (verbal), pengamatan (observation) untuk memahami sikap/tindakan yang terjadi, dan dokumentasi yang berupa tulisan, gambar, rekaman, atau foto.

Instrumen utama dalam penelitian ini adalah peneliti sendiri (Sugiyono, 2010) didukung dengan instrumen lainnya, yaitu pedoman wawancara dan pedoman observasi. Data dianalisis secara deskriptif menurut Miles dan Huberman (Miles dan Huberman, 1992) yaitu pengumpulan data, reduksi data, penyajian data, dan penarikan kesimulan atau verifikasi. Untuk mengecek keabsahan data dilakukan dengan ketekunan pengamatan dan triangulasi. Triangulasi yang diterapkan adalah triangulasi sumber dan teknik. Peneliti mengecek keabsahan data melalui beberapa sumber dan teknik, seperti melakukan wawancara dengan kepala sekolah, guru kelas dan siswa, kemudian mengecek hasil wawancara dengan hasil observasi dan dokumentasi.

\section{HASIL PENELITIAN DAN PEMBAHASAN}

Penelitian ini bertujuan untuk mendeskripsikan bagaimana implementasi pembelajaran tematik integratif berbasis karakter di SDIT Kota Jambi. Peneliti melakukan analisis secara kualitatif proses perencanaan, pelaksanaan, penilaian pembelajaran tematik integratif di dua SDIT Kota Jambi, yaitu SDIT An-Nahl dan SDIT Ash-Shiddiqi. Analisis dilakukan dengan melakukan observasi, wawancara, dan analisis dokumen berupa silabus, RPP, dan dokumen lainnya. Observasi dilakukan di kelas IV. Hal ini dikarenakan pada tahun ajaran 2017/2018, kedua sekolah ini baru menerapkan K13 di kelas I dan IV. Sedangkan wawancara dilakukan dengan kepala sekolah dan wali kelas yang diobservasi.

Perencanaan Pembelajaran Tematik : Setiap proses pembelajaran diawali dengan perencanaan. Perencanaan yang baik adalah setengah dari keberhasilan sebuah proses pembelajaran. Sekolah memfasilitasi guru-guru untuk membuat perangkat pembelajaran dengan menyediakan waktu khusus pada libur semester atau pada hari sabtu ketika tidak ada kegiatan pembelajaran. Hal ini dibuktikan dari hasil wawancara dengan kepala sekolah SDIT An-Nahl seperti berikut.

$P \quad$ : "Bagaimana persiapan pembelajaran tematik integratif di sekolah ini, Bu?"

J : "Persiapannya adalah memberikan waktu khusus kepada guru untuk membuat prota, prosem, dan silabus. Contohnya, kemarin waktu anakanak kelas 6 UN, selama seminggu full guru-gurunya mengerjakan prota, prosem, dan silabus sampai selesai. Kalo RPP nya sendiri, memang 
rutin dibuat terus setiap bulan sebagai salah satu syarat bagi kita untuk mengambil kafalah juga." (wawancara pada hari Senin, 21 Mei 2018)

Hal senada juga disampaikan oleh kepala sekolah SDIT Ash-Shiddiqi yang tersirat pada petikan wawancara berikut.

“... sekolah juga mengadakan pelatihan untuk guru-guru menyusun perencanaan pembelajaran pada kurikulum k13 selama satu minggu full. Biasanya kami mengundang pemateri dari Dinas atau LPMP untuk membimbing kami dalam proses penyusunannya." (wawancara pada hari Kamis, 24 Mei 2018)

Dengan demikian, bahwa proses pembelajaran di SDIT dimulai dengan perencanaan pembelajaran yang matang. Hal ini terlihat bahwa sekolah memberikan fasilitas bagi guru untuk mempersiapkan semua perangkat pembelajaran. Ini menunjukkan bahwa sekolah memperhatikan output proses pembelajaran, karena telah memfasilitasi dalam perencanaan pembelajaran. Hal ini sesuai dengan pendapat Sabri bahwa tanpa perencanaan, pelaksanaan suatu kegiatan akan mengalami kesulitan dan bahkan kegagalan dalam mencapai tujuan yang diinginkan (Sabri, 2007)

Selain itu, dengan membuat perencanaan akan menghadirkan banyak manfaat, seperti: (a) sebagai petunjuk arah kegiatan dalam mencapai tujuan; (b) sebagai pola dasar dalam mengatur tugas dan wewenang bagi setiap usur yang terlibat dalam kegiatan; (c) sebagai pedoman kerja/aktivitas guru dan murid; (d) sebagai alat ukur keefektifan pembelajaran; (e) menghemat waktu, tenaga, dan biaya (Majid, 2014). Perangkat perancanaan pembelajaran meliputi silabus dan RPP. Sebagaimana yang dikemukakan oleh Daryanto bahwa silabus dan RPP adalah hal-hal yang harus diperhatikan dalam persiapan pembelajaran tematik, yang sebelumnya harus dimulai dengan langkah membuat pemetaan standar kompetensi, kompetensi dasar, indikator dalam tema, kemudian menetapkan jaringan tema (Daryanto, 2014). Berikut ini disajikan hasil analisis dokumen silabus dan RPP. Silabus: Setelah dilakukan analisis dokumen silabus, ditemukan bahwa pada SDIT ditemukan keterpaduan, yakni keterpaduan antara materi yang dipelajari dengan ayat Al-Qur'an, hadist, atau shiroh (sejarah). Keterpaduan ini mengacu kepada standar mutu yang telah ditentukan oleh JSIT (Jaringan Sekolah Islam Terpadu). Hal ini seperti yang tertuang dalam kutipan wawancara berikut ini.

$P \quad$ : "Bagaimana dengan pengintegrasian karakter dalam proses pembelajaran"

$J \quad$ : "Nah, karakter ini selain dituntut oleh dinas untuk penguatan karakter, dari JSIT juga dituntut untuk pembinaan akhlak anak dulu. Nah jadi, dari selain sepuluh muashofat, dalam proses pembelajaran kita masukkan keterpaduan. 
Keterpaduan ini maksudnya dalam proses pembelajaran harus ada muatan ayat Al-qur'an atau hadist, atau shiroh. Jadi anak-anak bisa lebih mengenal atau ma'rifat kepada Allah." (wawancara dengan guru Ash-Shiddiqi pada hari Kamis, 24 Mei 2018)

Selain itu, juga ditemukan karakter yang dituntut oleh Pemerintah untuk dilakukan penguatan dalam proses pembelajaran, seperti sikap disiplin dan tanggungjawab. Hal ini bersesuaian dengan peraturan yang dibuat oleh Pemerintah, bahwa dalam silabus dan RPP harus dimuat pengitegrasian nilai-nilai karakter yang dikembangkan dalam proses pembelajaran (Kemendikbud, 2013).

Rencana Pelaksanaan Pembelajaran: RPP yang digunakan guru dalam penelitian ini adalah pembelajaran dengan tema Selalu Berhemat Energi dengan subtema Sumber Energi. Secara umum berdasarkan hasil analisis dokumen RPP yang dibuat oleh guru memuat aspek sebagai Yaitu: (1). Identitas: Berdasarkan analisis dokumen RPP dari dua SDIT yang diteliti, penulis menemukan perbedaan unsur dalam poin identtas. Identitas RPP yang digunakan di SDIT An-Nahl terdiri dari nama mata pelajaran, tema, subtema, pembelajaran, kelas/semester, alokasi waktu dan tanggal. Nama mata pelajaran diisi mata pelajaran yang dipelajari, yaitu tematik. Tema dan subtema berisikan tentang tema dan subtema yang dipelajari. Pembelajaran adalah urutan pembelajaran yang dipelajari dalam satu subtema. Alokasi waktu diperhitungkan untuk mencapai suatu kompetensi dasar dan dinyatakan dalam jam pelajaran dan banyaknya pertemuan. Sedangkan unsur identitas RPP SDIT Ash-Shiddiqi terdiri dari satuan pendidikan, yang diisi dengan nama sekolah; kelas/semester; tema dan subtema; alokasi waktu; dan pembelajaran ke-, yang diisi dengan urutan proses pembelajaran yang dilakukan. Namun, perbedaan yang ditemukan tidak menghilangkan tujuan dari dicantumkannya identitas dalam RPP, yang memuat tentang keterangan proses pembelajaran dilaksanakan. RPP dibuat untuk satu kali pembelajaran, dengan alokasi waktu satu hari. (2).Kompetensi Inti Pada RPP yang dibuat guru, sudah tercantum KI-1 sampai KI-4, yaitu KI-1 tentang sikap religius, KI-2 tentang sikap sosial, KI-3 tentang kognitif atau pengetahuan, dan KI-4 tentang psikomotorik atau keterampilan. Perumusan KI sudah ditetapkan oleh pemerintah, sehingga telah menunjukkan adanya pengintegrasian nilai karakter yang dikembangkan. (3). Kompetensi Dasar dan Indikator Pencapaian Kompetensi: Kompetensi dasar adalah sejumlah kompetensi yang memberikan gambaran bahwa peserta didik telah mencapai standar 
kompetensi. Kompetensi dasar adalah turunan dari KI, sedangkan indikator adalah turunan dari KD. Kompetensi dasar dan indikator yang dimuat meliputi mata pelajaran Bahasa Indonesia, IPS, dan IPA. Indikator yang dituliskan juga sudah memuat indikator dalam spiritual, sikap, pengetahuan, dan keterampilan.

(4). Tujuan: Tujuan pembelajaran ditetapkan berdasarkan pengalaman belajar peserta didik. Tujuan belajar memuat capaian materi yang akan dipelajari oleh peserta didik. Berdasarkan hasil analisis dokumen, bahwa tujuan pembelajaran yang ditulis sudah sesuai dengan hal tersebut, yaitu menggambarkan tentang aktivitas belajar yang dilakukan siswa untuk mencapai tujuan pembelajaran yang diharapkan. (5). Materi Pembelajaran, Materi pembelajaran berisikan capaian yang akan dilakukan selama proses pembelajaran. Materi dikutip dari materi pokok yang ada pada silabus yang kemudian dikembangkan menjadi uraian materi. (6). Keterpaduan, Keterpaduan berisi keterkaitan materi pelajaran dengan ayat Al-qur'an, hadist, dan shiroh. Semua mata pelajaran yang termuat dalam pembelajaran tematik ada keterkaitannya dengan ayat Al-qur'an, hadist, dan shiroh. (7). Pendekatan dan Metode Pembelajaran, Pendekatan dan metode pembelajaran berisi pendekatan dan metode yang digunakan guru selama proses pembelajaran. Pendekatan pembelajaran yang digunakan guru adalah pendekatan saintifik, yaitu pendekatan yang memuat kegiatan 5M. Kegiatannya meliputi mengamati, menanya, menalar, mencoba, dan mengkomunikasikan. Kelima kegiatan ini akan tersurat dalam poin selanjutnya, yaitu langkah-langkah pembelajaran.

Sedangkan metode pembelajaran adalah cara yang digunakan guru untuk menyampaikan pesan (pembelajaran) kepada peserta didik. Metode pembelajaran yang tercantum adalah ceramah, tanya jawab, diskusi, dan unjuk kerja. Metode yang digunakan guru telah sesuai dengan materi dan kegiatan yang akan dilakukan oleh peserta didik. Metode ini juga dapat digunakan untuk mengembangkan nilai-nilai karakter. Hal ini seperti yang diungkapkan oleh guru ketika wawancara, bahwa:

\footnotetext{
$P \quad: \quad$ Menurut Ibu, metode apa yang paling efektif untuk menanamkan karakter kepada siswa"

J : " Anak akan lebih mudah paham dan tertarik dengan cara bercerita, apalagi dengan cerita-cerita yang dekat dengan kehidupan sehari-harinya, sehingga mereka lebih cepat memahami dan tau apa resikolakibat dari perbuatan yang akan dilakukannya." (wawancara dengan guru Ash-Shiddiqi pada hari Rabu, 9 Mei 2018)
} 
(8). Kegiatan Pembelajaran: Kegiatan pembelajaran terdiri dari pendahuluan, inti, dan penutup. Berdasarkan hasil analisis, bahwa dalam kegiatan pembelajaran telah menunjukkan pengintegrasian pembelajaran tematik berbasis karakter dan telah sesuai dengan pendekatan saintifik yang dicantumkan dalam poin pendekatan pembelajaran. Beberapa kegiatan pembelajaran yang mencerminkan karakter religius dan disiplin yang tertulis dalam RPP terdapat pada bagian pendahuluan, yaitu guru dan siswa bersama-sama mengucapkan basmallah untuk membuka pelajaran. (9). Penilaian: Penilaian berisikan tentang cara memberikan penilaian terhadap kompetensi yang telah dicapai siswa selama proses pembelajaran. Penilaian yang dilakukan meliputi penilaian spiritual, sikap, unjuk kerja, dan pengetahuan. Penilaian sikap, unjuk kerja dan spiritual yang digunakan adalah dengan observasi. Sedangkan penilaian pengetahuan dilakukan dengan tes (10). Media/Alat, Bahan dan Sumber Belajar Media yang digunakan dalam pembelajaran cukup beragam seperti teks bacaan, gambar, dan lain-lain. Sumber belajar yang digunakan oleh guru juga variatif dan tidak tergantung pada buku guru dan buku siswa yang telah ditetapkan oleh pemerintah. SDIT menggunakan buku pegangan siswa agar siswa dapat belajar dengan efektif. Hal ini dapat dilihat pada daftar pustaka yang dituliskan dan berdasarkan hasil wawancara, sebagai berikut.

“ Kami memfasilitasi siswa dengan buku pegangan, karena kalo buku dari Dinas kan gak boleh dicoret-coret. Jadi siswa bisa belaja lebih efektif dan gak perlu banyak-banyak mencatat." (wawancara dengan kepala sekolah An-Nahl pada hari senin, 21 Mei 2018)

Dengan demikian, berdasarkan analisis dokumen bahwa silabus dan RPP yang disusun oleh SDIT bersesuaian dengan format dan ketentuan silabus dan RPP yang telah dibuat pemerintah. Namun, ada penambahan kurikulum keterpaduan JSIT yang berisi tentang keterpaduan materi yang dipelajari dengan ayat al-qur'an, hadist, dan shiroh. Hal ini bersesuaian dengan Robingatin (Robingatin, 2015) bahwa kurikulum JSIT melengkapi kurikulum nasional, dengan melakukan internalisasi nilai-nilai islam didalamnya. Temuan lain yaitu, guru mengungkapkan bahwa terkadang proses pembelajaran tidak berjalan sesuai dengan perencanaan. Hal ini disebabkan oleh beberapa faktor, seperti yang diutarakan oleh guru SDIT Ash-Shiddiqi dalam wawancara berikut.

“... dan ketika kita mengajarkan itu, jauh dari RPP. Pagi-pagi kita mau mengajarkan apa nih. Ada kejadian anak yang paginya murung, nangis, jadi kita ke dia dulu baru masuk ke pembelajarannya. Jadi lain dengan yang sudah direncanakan, dan itu sering." (wawancara pada hari Rabu, 9 Mei 2018) 
Selain itu juga, ketidaksesuaian antara perencanaan yang telah dibuat dengan pelaksanaannya adalah dikarenakan dalam satu minggu, sudah ditetapkan harus selesai enam PB (Proses Belajar), namun di SDIT hari efektir belajarnya hanya senin sampai jum'at. Jadi, satu PB digabung ke PB lainnya. Hal ini seperti yang diungkapkan dari hasil wawancara berikut.

“... kalo RPP kan benaran per pembelajaran tuh, nah jadi satu hari satu PB kan.

Kalo dari dinaskan seminggu 6 PB, kalo kami kan cuma lima hari, jadi 1 PB digabung ke PB yang lainnya."

Dengan demikian, ditemukan bahwa pada SDIT tetap membuat enam RPP untuk enam PB selama satu minggu. Namun, dalam pelaksanaannya disiasati menjadi lima PB. Sehingga pelaksanaan pembelajaran tidak berlangsung sesuai dengan perencanaan pembelajaran yang telah disusun. Hal ini adalah salah satu bentuk kreatifitas guru agar mampu menyesuaikan dengan kondisi yang terjadi, namun tetap mengarahkan proses pembelajaran agar indikator dan tujuan pembelajaran tercapai. Pembelajaran adalah suatu proses yang dinamis. Jadi, perubahan yang terjadi dalam pelaksanaan proses pembelajaran yang telah direncanakan adalah sebuah keniscayaan.

Pelaksanaan Pembelajaran Tematik: Berdasarkan hasil observasi ditemukan bahwa SDIT Kota Jambi dalam pelaksanaan pembelajaran tematik integratif telah menyisipkan nilai-nilai karakter yang dikembangkan, khususnya karakter religius dan disiplin yang diteliti dalam penelitian ini. Hal ini dilaksanakan selain karena tuntutan kurikulum juga dari JSIT untuk pembinaan akhlak peserta didik. Hal ini diperkuat dengan hasil wawancara yang dikutip berikut ini.
$P \quad: \quad$ "Bagaimana dengan pengintegrasian karakter dalam proses pembelajaran"
J : "Nah, karakter ini selain dituntut oleh dinas untuk penguatan karakter, dari JSIT juga dituntut untuk pembinaan akhlak anak dulu" (wawancara dengan kepala sekolah An-Nahl pada hari Senin, 21 Mei 2018)

Selain itu, pembelajaran tematik integratif ini pun secara otomatis telah menanamkan nilai-nilai karakter kepada siswa. Hal ini seperti yang dituturkan oleh guru berikut.

\footnotetext{
“ Misalnya nih kita belajar tentang energi, ketika mengetahui tentang energi, IPA nya kan belajar tentang macam-macam energi, IPS nya bagaimana menghemat energi, dan ketika PKN-nya menjaga lingkungan agar energi tetap terjaga dan tidak cepat habis, akhirnya mereka "ooh, begini yaaa", jadi ujungnya mereka dapat mengaplikasikannya. Jadi, ketika mereka tau macam-macam energi, akhirnya mereka bisa menghemat energi, dan akhirnya mereka bisa menjaga
} 
lingkungan agar energi tetap terjaga. Ada orang tua siswa cerita, "Bu kata anak saya sekarang "Mah, hemat energi!". Padahal kan dulu dia kalo mandi airnya suka banyak, entah kena kebadan ntah nggak." Itu sederhana, tapi akhirnya berdampak. Mudah-mudahan sampai mereka dewasa. Akhirnya kan terbangun juga karakter peduli, tanggung jawab, jadi kan dia tanggung jawab dalam penggunaan air. Peduli dia terhadap air, kalo air habis bagaimana? (wawancara dengan guru Ash-Shiddiqi pada hari Rabu, 9 Mei 2018).

Pada proses pelaksanaan pembelajaran ditemukan bahwa pada setiap materi selalu dikaitkan dengan karakter religius. Hal ini dikarenakan memang visi dan misi dari SDIT adalah membentuk peserta didik yang agamis dan berakhlakul karimah. Dalam proses pelaksanaan pembelajaran tematik berbasis karakter di SDIT Kota Jambi, nilai-nilai karakter yang diteliti secara mendalam adalah karakter religius dan disiplin. Berikut ini diuraikan secara jelas bagaimana nilai-nilai karakter tersebut tampak dalam tahapan proses pembelajaran yang meliputi kegiatan pendahuluan, kegiatan inti, dan kegiatan penutup.

a) Kegiatan Pendahuluan: Berdasarkan hasil observasi lapangan, pada kegiatan pendahuluan tampak aktivitas siswa yang mengembangkan karakter disiplin, meliputi: (1). Datang tepat waktu: Hasil catatan lapangan menunjukkan bahwa siswa tiba di sekolah 10-15 menit sebelum bel berbunyi. Ketika tiba di sekolah, siswa langsung masuk kelas, berwudhu, dan melaksanakan sholat dhuha di dalam kelas (Catatan Lapangan di SDIT An-Nahl). Sedangkan siswa di SDIT Ash-Shiddiqi, ketika tiba disekolah siswa sudah dalam keadaan berwudhhu. Hal ini menunjukkan bahwa SDIT menanamkan karakter disiplin dalam proses pembelajaran. (2). Mematuhi peraturan yang berlaku; Karakter mematuhi peraturan yang berlaku dikembangkan melalui pembiasaan siswa, bahwa ketika datang ke sekolah, siswa langsung menyimpan sepatu di rak dengan rapi (selain hari senin dan kamis, karena hari senin upacara, dan hari kamis senam) (Catatan lapangan di SDIT An-Nahl dan Ash-Shiddiqi).

Ketika bel berbunyi, semua siswa berdiri di depan kelas, berbaris rapi, streching (pemanasan), kemudian bersama-sama membaca ikrar siswa. Aktivitas ini mengembangkan karakter disiplin. Hal ini dikarenakan setiap pagi siswa membaca ikrar untuk mematuhi segala peraturan yang berlaku. Sedangkan karakter religius dalam kegiatan pendahuluan, yaitu: (1). Mengucapkan salam: Ketika siswa 
memasuki ruangan kelas, guru memulai dengan mengucapkan salam dan mengajak siswa untuk bersama-sama membaca basmallah.

"Ayo anak-anak Ustazah, kita mulai dulu aktivitas kita hari ini dengan melafazkan basmallah, agar apa? Yah, agar setiap aktivitas kita memperoleh ridho dan keberkahan dari Allah SWT"(Catatan lapangan pada hari Senin dan Rabu pada tanggal 7 dan 9 Mei 2018)

Hal ini diperkuat dengan hasil wawancara bahwa guru mengajarkan kepada anakanak untuk mengucapkan salam setiap kali bertemu dengan ustaz/ahnya.

“Kami membiasakan 5S, Senyum, salam, sapa, sopan, dan santun."(wawancara dengan guru SDIT Ash-Shiddiqi pada hari Rabu, 9 Mei 2018)

Hal ini juga didukung dengan hasil wawancara bersama peserta didik, sebagai berikut.

P $\quad$ : "Apakah Bapak/Ibu guru mengajarkan untuk memberi salam kepada Bapak/Ibu guru?"

SS : : Iya, kami diajarkan untuk mengucapkan salam setiap kali bertemu." (wawancara dengan siswa Ash-Shiddiqi pada hari Rabu, 9 Mei 2018)

SA : "Iya, guru-guru disini mengajarkan kami untuk slalu 5S, senyum, salam, sapa, sopan, dan santun." (wawancara dengan siswa An-Nahl pada hari Senin, 7 Mei 2018)

(2). Berdoa sebelum belajar Setelah mengucapkan basmallah, guru dan siswa bersama-sama membaca zikir pagi, kemudian dilanjutkan dengan murojaah hafalan qur'an dan doa sebelum belajar. Hal ini untuk membentuk karakter siswa agar terbiasa memulai aktivitas dengan zikir dan doa. Sebagaimana yang diutarakan oleh kepala sekolah An-Nahl dalam kutipan wawancara berikut.

"Selain itu, kami ada waktu 15 menit untuk bina karakter. Akivitas anak yang wajib di pagi hari adalah ikrar, toilet training, sholat dhuha, habis itu bina karakter, murojaah dan hafalan hadist dan doa. Bina karakter misanya masuk ruangan: ketok tiga kali, kemudian mengucapkan salam, setelah dijawab salamnya baru tanya, boleh masuk nggak? Setelah dijawab boleh, baru masuk ruangan."(wawancara pada hari Senin, 21 Mei 2018).

Untuk mengembangkan karakter siswa, metode yang digunakan adalah metode simulasi dan pembiasaan. Hal ini seperti yang diungkapkan dalam kutipan wawancara berikut.

P : : "Bagaimana cara mengajarkan karakter kepada siswa?"

J :"... dengan simulasi. Misalnya cara masuk ruagan dengan benar, dipraktekkan satu-satu. Cara menyimpan sepatu dirak, sampai sholat dhuha. Selain itu juga dengan teknik pembiasaan. Misalnya ada siswa izin ke toilet kemudian masuk ruangan tanpa mengerjakan adab masuk ruangan, maka guru menyuruh untuk mengulangi kembali sampai benar. "(wawancara pada hari Senin, 21 Mei 2018) 
Untuk melaksanakan metode pembiasaan ini, guru harus sabar dan harus seringsering mengingatkan siswa dan menciptakan kreativitas sendiri untuk bercerita kepada anak tentang pembiasaan karakter baik. Sebagaimana yang diungkapkan dari hasil wawancara dengan guru Ash-Shiddiqi berikut.

"In syaa Allah, dengan seringnya kita mengingatkan adalah satu atau dua yang mereka ingat. Dan anak-anak itu lebih cepat paham dengan cara bercerita, karena fitrahnya anak-anak kan suka mendengarkan cerita. Apalagi jika diceritakan kisah-kisah yang dekat dengan kehidupannya sehari-hari. Anak jadi tau alasan kenapa harus melakukan ini dan kenapa tidak boleh melakukan itu. "'(wawancara pada hari Rabu, 9 Mei 2018)

Hasil analisis dokumen RPP juga menunjukkan bahwa guru dan peserta didik selalu mengucapkan salam dan membaca doa sebelum memulai pembelajaran yang tertera pada kegiatan pendahuluan pembelajaran.

b). Kegiatan Inti Pada kegiatan inti, telah memasuki inti dari pembelajaran. Karakter disiplin yang diamati selama proses pembelajaran adalah: (1). Tertib dalam pelaksanaan pembelajaran; Selama proses pembelajaran berlangsung, siswa mengikuti dengan tertib. Ketika ada siswa yang mau izin ke toilet, maka siswa tersebut meminta izin terlebih dahulu kepada guru (catatan lapangan pada hari Senin dan Rabu, tanggal 7 dan 9 Mei 2018). Menyimpan barang pribadi dengan rapi. Siswa diajarkan untuk menempatkan segala sesuatu pada tempatnya dan disimpan dengan rapi. Hal ini tampak dari hasil pengamatan, bahwa siswa mempunyai satu tas untuk menyimpan barang pribadi (yang berkaitan dengan pembelajaran) miliknya (2). Mengikuti arahan/bimbingan guru

Selama proses pembelajaran berlangsung, ada beberapa siswa yang heboh dengan sendirinya atau bersama dengan beberapa temannya adalah sebuah keniscayaan. Sehingga, guru terlihat lebih sering mengingatkan siswa agar tidak ribut, agar menghargai pendapat temannya, agar saling berbagi. Mendengar arahan dari guru tersebut, anak-anak mendengarkan dan mematuhinya (hanya untuk beberapa saat) dan kemudian diulangi kembali (catatan lapangan pada hari Senin dan Rabu, tanggal 7 dan 9 Mei 2018). 
Aktivitas seperti ini adalah sebuah kewajaran, karena masa usia anak-anak adalah usia yang aktif bergerak dan selalu ingin tahu. Seperti ungkapan yang disampaikan oleh kepala sekolah An-Nahl pada saat wawancara berikut.

"Imam Syafii aja butuh waktu 30 tahun untuk belajar adab saja, apalagi anakanak kita. Jadi sebagai pendidik kita harus sabar dan menjadi teladan yang baik untuk anak didik kita." (wawancara pada hari Senin, 21 Mei 2018)

Sedangkan karkater religius yang diamati secara mendalam pada kegiatan inti pembelajaran adalah mengingat kebesaran Allah swt. Selain nilai nilai karakter yang dituntut oleh pemerintah untuk dikembangkan dalam proses pembelajaran seperti peduli, tanggungjawab, bekerjasama, saling bebagi, dan lain sebagainya, SDIT menanamkan nilai ketauhidan. Setiap materi yang disampaikan dalam pembelajaran tematik selalu dikaitkan dengan ayat Al-qur'an, hadist, dan shiroh, yang disebut dengan kurikulum keterpaduan SIT.

Hal ini didukung dengan hasil wawancara berikut.

"Setiap proses pembelajaran, kita slalu menambahkan khas SIT nya. Misalkan tentang energi tadi, kalo di buku yang dibuat sama Pemerintah tidak ada muncul ayat-ayat alqur'annya, misalkan asy-syam, ada matahari. Jadi kita masukkan dibagian pendahuluan pada apersepsi, bahwa contoh energi terbesar yang ada di bumi ini adalah matahari, dan ternyata dalam alqur'an juga ada menjelaskan tentang itu. Sedikit-sedikit saja sih penambahan ayat al-qur'annya, gak terlalu banyak. "(wawancara dengan guru Ash-Shiddiqi pada hari Rabu, 9 Mei 2018)

"Disetiap materi, kami selalu mengusahakan adanya keterpaduan dengan ayat Alqur'an, atau kalau gak ada berkaitan dengan hadist atau shiroh. Dan biasanya itu sudah tertera dalam standar mutu SIT, tapi ada juga yang tidak ada jadi kami berinisiatif mencari sendiri keterpaduannya." (wawancara dengan guru An-Nahl pada hari Senin,7 Mei 2018)

Keterkaitan materi pelajaran dengan ayat al-qur'an bertujuan agar anak-anak mengetahui bahwa segala sesuatu yang ada di muka bum ini sudah diatur dengan rapi oleh Allah swt, sehingga rasa cinta dan syukur akan kebesaran Allah akan tumbuh dan berkembang dalam diri siswa. Hal ini seperti yang diungkapkan oleh kepala sekolah AnNahl bahwa:

"Keterpaduan ini maksudnya dalam proses pembelajaran harus ada muatan ayat Al-qur'an atau hadist, atau shiroh. Jadi anak-anak bisa lebih mengenal atau ma'rifat kepada Allah." (wawancara dengan guru Ash-Shiddiqi pada hari Kamis, 24 Mei 2018)

Hasil analisis dokumen RPP juga ditemukan bahwa ada poin keterpaduan dalam dokumen RPP yang dibuat oleh SDIT yang berisi: Bahasa Indonesia (Qs. Ar-Rum:48), 
IPS (As. Al-An'am:99), dan IPA (Qs. Ar-Rum:48). Selain itu pada bagian langkah pembelajaran tentang energi alternatif pengganti minyak bumi dan gas alam juga dituliskan. Bahwa angin adalah energi alternatif dan siswa melakukan eksperimen membuat kincir angin, kemudian dituliskan terjemahan ayat A-qur'an yang dituliskan seperti.

Guru menjelaskan keterpaduan Qs. Ar-Rum:48

"Allah, Dialah yang mengirim angin, lalu angin itu menggerakkan awan dan Allah membentangkannya di langit menurut yang dikehendakiNya dan menjadikannya bergumpal-gumpal, lalu kamu lihat hujan keluar dari celahcelahnya. Maka apabila hujan itu turun mengenai hamba-hambaNya akan dikehendakiNya, tiba-tiba mereka menjadi gembira."

Kemudian ketika membahas tentang daun jarak sebagai energi alternatif, guru menyampaikan keterpaduannya dengan ayat Al-qur'an di bawah ini.

Guru menjelaskan keterpaduan Qs. Al-An-am:99

"Dan Dialah yang menurunkan air hujan dari langit, lalu kami tumbuhkan dengan air itu segala macam tumbuh-tumbuhan. Maka kami keluarkan dari tumbuh-tumbuhan itu tanaman yang menghijau. Kami keluarkan dari tanaman yang menghijau itu butir yang banyak: dan dari mayang korma mengurai tangkaitangkai yang menjulai, dan kebun kebun anggur, dan (Kami keluarkan pula) zaitun dan delima yang serupa dan yang tidak serupa. Perhatikanlah buahnya diwaktu pohonnya berbuah dan (perhatikan pulalah) kematangannya. Sesungguhnya pada yang demikian itu ada tanda-tanda kekuasaan Allah bagi orang yang beriman."

Hasil wawancara dengan siswa juga menunjukkan nilai positif. Berikut transkip wawancara dengan siswa.

$P \quad: \quad$ "Apakah ketika Ustaz/ah mengajar selalu mengaitkan materi yang dipelajari dengan ayat-ayat Al-qur'an?"

SA : "Iya" (wawancara pada hari Senin, 7 Mei 2018)

SS : :"Iya, selalu" (wawancara pada hari Rabu, 9 Mei 2018)

$P \quad: \quad$ "Apa yang ananda dapat pelajari ketika Ustaz/ah mengaitkan materi dengan ayat-ayat Al-qur'an?"

SA : :Saya jadi tau bahwa Allah itu Maha Besar dan segala sesuatu yang ada di bumi ini adalah milik Allah" (wawancara pada hari Senin, 7 Mei 2018)

SS : :"Ternyata yah bu, ilmu Allah ituuu luaaasss banget. Ilmu yang saya pelajari di sekolah ini cuma dikit, cuma kayak butiran debu ajah. " (wawancara pada hari Rabu, 9 Mei 2018)

c). Kegiatan Penutup; Kegiatan penutup adalah kegiatan akhir dalam proses pembelajaran. Berdasarkan hasil observasi kegiatan ini diisi dengan kesimpulan dan penyampaian materi yang akan dipelajari pada hari berikutnya (catatan lapangan pada 
hari Senin dan Rabu tanggal 7 dan 9 Mei 2018). Sebelum siswa ke mushola untuk melaksanakan sholat ashar, guru menyampaikan pesan cinta ustazah. Berisi tentang nasihat agar peserta didik menjaga sholat, menjaga aurat, menjaga tilawah, berbuat baik kepada orang lain, dan lain-lain. Hal ini seperti yang diungkapkan dari hasil wawancara dengan siswa berikut ini.

$P \quad \quad \quad$ :Aktifitas apa yang dilakukan oleh guru sebelum mengakhiri pembelajaran?"

SA : :Bu Siska menyampaikan pesan cinta untuk kami, supaya nanti kalo keluar rumah harus pake jilbab, pakai kaos kaki. Trus juga ngingetin untuk sholat tepat waktu kalo bisa berjamaah. Ngingetin buat tilawah juga ibu nya." (wawancara pada hari Senin, 7 Mei 2018)

$S S$ :"Hmmm, apa ya? Buat kesimpulan terus ngingetin besok belajar tentang apa dan harus bawa apa aja." (wawancara pada hari Rabu, 9 Mei 2018)

Hasil analisis terhadap dokumen RPP juga menunjukkan hal yang sama dengan apa yang telah dikemukakan di atas.

Berdasarkan hasil penelitian tentang pelaksanaan pembelajaran tematik di atas, ditemukan bahwa guru menanamkan nilai-nilai karakter religius dan disiplin kepada siswa. Hal ini sesuai dengan pendapat Marzuki (Marzuki, 2012) bahwa pengintegrasian nilai karakter dalam kegiatan pembelajaran dimulai dari kegiatan pendahuluan, inti, dan penutup. Untuk menanamkan pendidikan karakter, metode yang biasa dilakukan oleh guru adalah dengan metode bercerita, pembiasaan, dan teladan. Hal ini senada Khoirida (Khoirida, 2013) yang mengemukakan bahwa metode pembelajaran pendidikan karakter dapat dilakukan dengan metode: keteladanan, bercerita, pembiasaan, karyawisata, story telling, diskusi, simulasi, dan pembelajaran kooperatif. Selama proses pembelajaran, guru selalu mengingatkan siswa untuk selalu bersyukur kepada Allah swt dengan cara rajin beribadah dan berbuat baik kepada sesama.

Penilaian Pembelajaran Tematik: Penilaian atau evaluasi adalah bagian dari sebuah pembelajaran. Penilaian adalah cara yang digunakan untuk mengukur sejauh mana tujuan pembelajaran dapat tercapai oleh peserta didik. Pada pembelajaran tematik, penilaian tidak hanya berdasarkan kemampuan kognitif, tapi juga sikap spiritual, sosial, dan keterampilan. Sehingga, proses penilaian dilakukan setiap waktu. Guru mengungkapkan bahwa penilaian seperti ini sangat menguntungkan bagi siswa, karena menggali semua potensi peserta didik tidak hanya kemampuan kognitif. Hal ini seperti yang diungkapkan oleh guru dalam transkip wawancara berikut. 
"Sistem penilaian seperti ini menguntungkan bagi anak. Karena penilaiannya menggabungkan aspek kogitif, afektif, dan psikomotorik. Sehingga potensi anak tergali. Ada yang matematikaya bagus, ada yang ipanya, ada yang sikap kewarganegaraanya bagus." (wawancara dengan guru SDIT Ash-Shiddiqi pada hari Rabu, 9 Mei 2018)

Dengan demikian, bahwa SDIT menerapkan penilaian autentik yang menilai semua aspek pembelajaran yang meliputi, spiritual, sikap, kognitif, dan keterampilan. Hal ini sesuai dengan Permendikbud No. 67 tahun 2013 yaitu tentang penilaian proses pembelajaran menggunakan penilaian autentik yang menilai kesiapan peserta didik, proses pembelajaran, dan hasil belajar secara utuh.

Penilaian kognitif adalah penilaian yang biasa dilakukan di sekolah, yaitu dengan menggunakan tes yang dapat dilakukan dengan ulangan harian, ujian formatif, dan ujian akhir semester. Pada pembelajaran tematik ini penilaian dilakukan pertema. Nilai akhir merupakan gabungan dari semua tema.

Sedangkan untuk penilaian sikap, guru menggunakan catatan penilaian seperti yang tercantum di RPP. Guru melakukan pengamatan terhadap sikap peserta didik selama proses pembelajaran berlangsung. Hasil pengamatan ditulis dalam sebuah buku catatan. Hal ini dilakukan guru sebagai pengingat dan bahan rujukan ketika memberikan penilaian sikap siswa. Sebagaimana yang diungkapkan oleh guru pada transkip wawancara berikut.

"Penilaian sikap dilakukan maksimal sebulan sekali. Kalau ada kejadian-kejadian khusus, ditangani saat itu juga, dituliskan dan dijadikan salah satu rujukan untuk memberikan nilai sikap sangat baik, baik, cukup, atau masih perlu bimbingan." (wawancara dengan guru SDIT Ash-Shiddiqi pada hari Rabu, 9 Mei 2018)

Guru mengungkapkan, untuk menghindari subjektifitas biasanya digabung antara penilaian guru dan penilaian antar teman. Hal ini seperti yang diutarakan dibawah ini.

“... Sebagai guru, menghilangkan subjektifitas itu agak susah, untuk mengatasinya ada penilaian antar teman dan penilaian guru, nanti digabungkan." (wawancara dengan guru SDIT Ash-Shiddiqi pada hari Rabu, 9 Mei 2018)

Penilaian antar teman di SDIT Ash-Shiddiqi dilaksanakan maksimal sebulan sekali. Setiap siswa mengisi form yang telah disediakan oleh guru dan memberikan penilaian terhadap temannya terkait dengan sikap. Hal ini sesuai dengan hasil wawancara dengan siswa seperti pada transkip di bawah ini.

$P \quad: \quad$ :Ananda pernah ngga memberikan penilaian untuk teman-temannya?"

SS : :Hmm, iya pernah, yang ngisi tabel tabel itu kan bu?" 


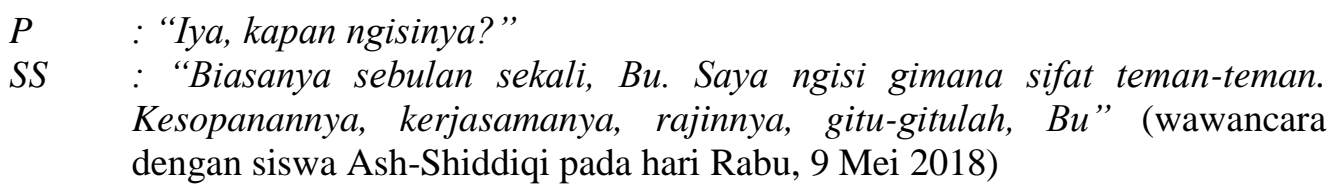

Sedangkan penilaian yang dilakukan oleh guru di SDIT An-Nahl pada setiap hari di akhir proses pembelajaran. Guru membuat catatan penilaian terhadap siswa selama proses pembelajaran hari itu. Hal ini sesuai dengan keterangan yang disampaikan oleh kepala sekolah SDIT An-Nahl seperti yang tertranskip di bawah ini.

$\mathrm{P} \quad$ : "Ada 4 ranah penilaian, spritual, kognitif, afektif, dan psikomorik. Bagaimana guru menilainya?

J $\quad$ : "Kami memberikan space bagi guru untuk menilai. Misalkannya nih anak pulang, guru belum boleh pulang dan menyelesaikan apa yang harus diselesaikan pada hari itu. Anak-anak pulang jam 3.45, guru pulang sekitar pukl 4.15 - 4.30, sama setiap hari sabtu adalah waktu khusus untuk guru belajar, microteaching, menyiapkan pembelajaran, mengisi nilai. Karena hidup kan dinamis, jadi butuh masukan dari orang lain.

Dengan demikian, bahwa SDIT menilai sikap siswa dengan melakukan pengamatan. Guru mengamati aktivitas atau perilaku baik sampai kurang baik. Jika hasil pengamatan menunjukkan perilaku baik, berarti siswa telah memenuhi indikator pembelajaran. Sebaliknya, jika hasil pengamatan menunjukkan perilaku kurang baik, guru mencatat perilaku tersebut didalam sebuah buku untuk dijadikan rujukan dalam memberikan penilaian. Penilaian sikap juga dilakukan dengan penilaian antar teman untuk meminimalisir subjektifitas guru dalam menilai. Hal ini sesuai dengan pendapat Zuchdi (Zuchdi, 2012) bahwa untuk menilai karakter harus dilakukan secara komprehensif, yang meliputi ranah pemikiran, perasaan, dan perilaku sehari-hari (kebiasaan).sedangkan kebaharuan penelitian ini adalah mmm Berdasarkan hasil penelitian, dapat disimpulkan bahwa: (a) Perencanaan pembelajaran tematik berbasis karakter di SDIT Kota Jambi terintegrasi nilai-nilai karakter dalam pembelajaran tematik dan Penilaian pembelajaran tematik dengan menggunakan penilaian autentik.

\section{KESIMPULAN DAN SARAN}

Berdasarkan hasil penelitian, dapat disimpulkan bahwa: (a) Perencanaan pembelajaran tematik berbasis karakter di SDIT Kota Jambi sudah menunjukkan adanya pengintegrasian nilai-nilai karakter dalam pembelajaran tematik, yang didukung dengan adanya pengintegrasian kurikulum keterpaduan di SDIT Kota Jambi; (b) Pelaksanaan pembelajaran tematik tidak berjalan sesuai dengan perencanaan, namun tidak 
menghilangkan tujuan pembelajaran dan pengintegrasian nilai karakter, dikarenakan hari aktif yang berlaku di SDIT Kota Jambi hanya lima hari; dan (c) Penilaian pembelajaran tematik di SDIT Kota Jambi dilakukan dengan menggunakan penilaian autentik. Saran dalam penulisan ini agar semua penmbelajaran tematik memperhatikan Prencanaan, pelaksanaan dan penilaian pembelajaran tematik di SDIT Kota Jambi

\section{DAFTAR PUSTAKA}

Bahri, S. (2010). Strategi Belajar Mengajar. Jakarta: Rineka Cipta.

Daryanto. (2014). Pembelajaran Tematik, Terpadu, Terintegrasi (Kurikulum 2013). Yogyakarta: Gava Media.

Dwi, S. (2007). Menulis Ilmiah Metode Penelitian Kualitatif. Jakarta: Yayasan Obor Indonesia.

Hikmawati, K. (2018). Implementasi Pembelajaran Tematik Berbasis Karakter Religius Dan Peduli Sosial Di Kelas IV SD Pusmalang. Jurnal Pendidikan Guru Sekolah Dasar, 5.

Kemendikbud. (2013). Panduan Teknis Penilaian di Sekolah Dasar Kurikulum 2013. Jakarta: Kementerian Pendidikan dan Kebudayaan.

Khoirida, M. . (2013). Pendidikan Karakter Anak Usia Dini. Yogyakarta: Ar-Ruzz Media. Kompas. (20015). www.edukasi.kompas.com. In 25/11/2015.

Majid, A. (2014). Pembelajaran Tematik integratif Terpadu. Bandung: PT. Remaja Rosdakarya.

Marzuki. (2012). Pengintegrasian Pendidikan Karakter dalam Pembelajaran di Sekolah. Jurnal Pendidikan Karakter, 2(1).

Miles dan Huberman. (1992). Qualitative Data Analisis, Terj Rosidi T.R. Jakarta: UI Press.

Robingatin. (2015). Implementasi Kurikulm Jaringan Islam Terpadu di SMP IT. Jurnal Syamil, 3(1).

Sabri, A. (2007). Strategi Belajar Mengajar Micro Teaching. Padang: Quantum Teaching. Sugiyono. (2010). Metode Penelitian Pendidikan: Pendekatan Kuantitatif dan Kualitatif. Bandung: Alfabeta.

Suryosubroto. (2009). Proses Belajar Mengajar di Sekolah. Jakarta: Rineka Cipta.

Tri Karyani, L. (2017). Implementasi Pembelajaran Tematik Integratif Dengan Pendekatan Scientific Pada Kelas 5 Sekolah Dasar Negeri Unggulan Di Kabupaten Purweroje. E-Jurnal Prodi Teknologi Pendidikan, 6(8), 756-760.

Trianto. (2011). Desain Pengembangan Pembelajaran Tematik Bagi Anak Usia Dini TK/RA \& Anak Anak Usia Kelas Awal SD/MI. Jakarta: Kencana Prenada Media.

Zuchdi, D. (2012). Panduan Implementasi Pendidikan Karakter Terintegrasi dalam Pembelajaran dan Pengembangan Kultur Sekolah. Yogyakarta: UNY Press. 